\title{
P-212
}

\section{Chemical Constituents of Two Malaysian Medicinal Plants: Scaphium Macropodum (Sterculiaceae) and Sapium Baccatum (Euphorbiaceae)}

\author{
Laode Muhammad Ramadhan Al Muqarrabun, Norizan Ahmat and Sharipah Ruzaina Syed Aris
}

Scaphium macropodum and Sapium baccatum are two Malaysian medicinal plants. S. macropodum, also known as malva nut (English) or Kembang Semangkuk Jantung (Malaysian), belongs to family Sterculiaceae [1], while $S$. baccatum, known as Ludai (Malaysian), is from family Euphorbiaceae [5]. These plants have been reported to possess medicinal properties. S. macropodum can be used to treat intestinal infections, diarrhoea, throat aches, asthma, dysentery, fever, coughs, inflammation, and urinary illness [3]. In China, it is also used as a traditional drug to prevent pharyngitis and also to treat tussis and constipation. It also has cooling agent properties [2]. The leaves of $S$. baccatum exhibit anti-inflammatory activity which is associated with alkaloid bukittinggine [4]. Isolation of chemical constituents from S. macropodum and S. baccatum were carried out using standard approaches usually used in natural products chemistry. Grounded, air-dried stem bark of the two species were macerated using methanol. The methanolic extracts were then subjected to rotary evaporator under reduced pressure to give crude extracts. Several chromatographic techniques, i.e. vacuum liquid chromatography (VLC) and radial chromatography (RC) were applied in the separation of chemical constituents of the sample. Purification of compounds obtained was carried out with crystallization technique. Three compounds were isolated from each of the samples. The structures of the isolated compounds were determined using several spectroscopic methods, i.e. UV-Vis, FT-IR, 1D and 2D NMR, and GC-MS. Lupeol (1), lupenone (2), and stigmasterol (3) were obtained from the stem bark of $S$. macropodum, while taraxerone (4), $\beta$-taraxerol (5), and propyl isoferulate (6) were isolated from the stem bark of $S$. baccatum.

Keywords: Scaphium macropodum, Sapium baccatum, lupeol, lupenone, stigmasterol, taraxerone, $\beta$-taraxerol, propyl isoferulate.

\section{REFERENCES}

[1] Kochummen KM. Sterculiaceae. In Whitmore, T.C. Ed., Tree Flora of Malaya. Longman: Kuala Lumpur 1972; vol. 2: pp. 353-82.

[2] Ray TK, Misra DR, Khastgir HN. Phytosterol in Euphorbiaceae and Rutaceae. Phytochemistry 1975; 14 : pp. $1876-7$.

[3] Lim TK. Edible medicinal and non-medicinal plants. Fruits USA: Springer, 2012; vol. 3: pp. 189-91.

[4] Lamxay V. Important Non-Timber Forest Products of Lao PDR. Lao PDR Forest Research Center, Vientiane 2001.

[5] Panthong A, Kanjanapothi D, Thitiponpunt Y, Taesotikul T, Arbain D. Anti-inflammatory activity of the alkaloid bukittinggine from Sapium baccatum. Planta Medica 1988; 64: pp. 530-5. 